\title{
THE HISTORY OF NON-PROFIT ORGANISATIONS \\ IN AUSTRALIA AS A TEST OF SOME RECENT \\ NON-PROFIT THEORY
}

MARK LYONS

CACOM WORKING PAPER NO. 7

JULY 1992

This paper was presented to the Third International Conference of Research on Voluntary and Nonprofit Organisations in Indianapolis, March 1992.

Mark Lyons is an Associate Professor in the School of Management at the University of Technology, Sydney. He is Director of the University's Centre for Australian Community Organisations and Management (CACOM). 


\section{CENTRE FOR AUSTRALIAN COMMUNITY ORGANISATIONS AND MANAGEMENT (CACOM)}

Community organisations are the product of group or community initiatives. They are formed to provide services to their members or to a wider public. Community organisations are particularly active in providing community services, health, housing, culture and recreation, education and training, finance, religion and in the organised representation of interests.

Community organisations are not run to make a profit for owners or shareholders and are not under the formal control of government. As a class they differ in important ways from both for-profit and government organisations. They differ in the ways they are governed, in the variety of their sources of income and in their frequent reliance on volunteers.

It is the mission of the Centre for Australian Community Organisations and Management (CACOM) to strengthen the Australian community sector and its management through research, management training and publication.

Among CACOM's objectives are:

- to promote a better understanding of the Australian community sector by undertaking and publicising basic research on its size, its resources, its management practices, its history and its relations with government and other sectors of the economy; and,

. to provide an information resource by collecting and disseminating research and other information vital to the community sector.

To this end CACOM sponsors a Working Paper Series.

Generally, CACOM Working Papers will publish research undertaken by CACOM members or encouraged by CACOM. The aim is to make the results of research widely available as quickly as possible to encourage discussion. In some cases, the research reported in a working paper will be further refined for refereed publication.

Working papers are distributed to academics, researchers, community sector managers, public servants and others who are interested in better understanding the Australian community sector.

If you wish to comment on this paper or seek further details of CACOM's activities and publications, write to:

The Director

Centre for Australian Community

Organisations and Management (CACOM),

University of Technology, Sydney,

Kuring-gai Campus, P O Box 222,

LINDFIELD NSW 2070, AUSTRALIA

Phone: (02) 3305311

Fax: (02) 3305583 


\section{CONTENTS}

\section{Page}

Introduction

Some Recent Theories 2

The History of Non-profit Organisations in Australia - An Overview 5

Seven Case Studies of Non-profit Growth and Development

Case 1: Private or Non-profit schools 8

Case 2: Friendly Societies 10

Case 3: The Loyal Orange Institution 11

Case 4: Legacy 11

Case 5: Building Societies 12

Case 6: Child Care 14

Case 7: Museums 15

$\begin{array}{ll}\text { Conclusions } & 16\end{array}$

$\begin{array}{ll}\text { References } & 18\end{array}$ 



\section{$\underline{\text { INTRODUCTION }}$}

Non-profit organisations are significant participants in a number of Australian industries. In many cases, theirs has been a pioneering role. They have also played an important part in creating and shaping Australia's social, economic and political institutions.

Non-profit organisations are the organisational manifestation of commitments by various groups of people to provide a service, to facilitate an activity or to advance a cause. They differ from government organisations because the effort that sustains them is voluntary and does not have the authority of government; they differ from for-profit organisations in that obtaining a personal profit from funds invested in the organisation was not their founders' nor their current participants' intention.

The activities of some non-profit organisations resemble those performed by government; others compete with for-profit organisations. Other activities, such as the performance of religious rituals or those aimed at overthrowing a regime, in most societies and polities, are exclusively organised in a non-profit (and non-government) form.

A number of relatively recent events, such as the questioning by the U.S. Congress of the tax status of foundations (Hall, 1987:20), the reconfiguration of the welfare state and, more recently, the collapse of communist regimes in Eastern Europe, have led to a great deal of attention being drawn to non-profit organisations, or at least to large sets of them. A good deal of that attention has been given by economists; a good deal of it has been devoted to trying to explain why non-profit organisations emerge and flourish in some fields of activity or industries and not in others.

These are important questions for historians as well as economists. The following paper seeks to review the adequacy of the most commonly cited, or popular, explanations for the origin and strength of non-profit organisations by testing their ability to explain important instances of the origins, growth and transformation of non-profit organisations in Australia. It is written by an historian who looks to other social sciences for ideas. It finds the popular economics-generated theories helpful but limited, largely because they are interested only in some of all possible types of non-profit organisations.

The paper briefly sketches the main features of these popular explanations. It then provides a brief overview of the development of non-profit organisations in Australia, using the conventional historians tool of periodisation based on significant changes. It goes on to examine in greater detail seven cases. Six are of the development of non-profit organisations in Australia. The seventh is of the development of government provision in a field where one of the commonly accepted theories posits the non-profit form. For each case the paper asks whether the popular explanations for the origins and growth of nonprofit organisations are sufficient to explain what happened. It concludes by drawing several implications from the preceding analysis. 


\section{SOME RECENT THEORIES}

One body of explanation for the existence of non-profit organisations has been advanced by Burton Weisbrod. Weisbrod notes that many non-profit organisations provide goods similar to those provided by government. He observes that governments provide certain goods (mostly but not exclusively collective-consumption goods) which they fund by raising revenue from taxation. In a democracy, any voter will be conscious of receiving these publicly provided goods but also of paying taxation. The government must strike a balance between the provision of goods and levels of taxation in a way which satisfies what Weisbrod calls the "median voter"; that is, in effect, the voter whose preference creates a majority for a particular trade-off of tax and service provision (satisfying just over $50 \%$ of the voting population). This will leave some with an unsatisfied demand for certain goods and a preparedness to pay more to obtain them. This demand will often be satisfied by non-profit organisations (Weisbrod, 1986).

In addition to this "excess" demand, Weisbrod argues that in societies where populations are divided by religion or ethnicity, the uniform provision of certain services such as education will be unable to satisfy all groups. Where this "hetereogeneity" or "differentiation" of demand exists, government provision will be limited and there will be a large non-profit provision. In short, Weisbrod postulates that non-profit provision of collective goods will be large in societies with high levels of inequality in individuals' effective demand for collective goods or high degrees of religious or ethnic heterogeneity.

By defining government provision to encompass government financed provision by nonprofit organisations, Weisbrod effectively limits the scope of his theory to non-profit organisations that rely exclusively on donations. Yet in many industries most services provided by non-profit organisations are funded by a combination of donations, government subsidies and, often, fees. Estelle James, who has developed Weisbrod's theory and sought to verify it via a number of comparative studies, accepts that services are non-profit if they are provided by a non-profit organisation, even if they are heavily subsidised by government (James, 1987).

Weisbrod has sought to give a historical dimension to his theory, proposing that non-profit provision will precede government provision. This is because until a particular set of collective goods is demanded by a majority of the electorate, the government will not provide them, but non-profit organisations will form to cater to the minority demand. As a corollary, Weisbrod is led to propose that the involvement by government in the provision of a particular set of collective goods does not come about as a result of some exogenously determined change in attitude towards government, but rather as a result of endogenous changes in demand variables such as income (Weisbrod, 1986).

Weisbrod's theory has been criticised for focussing its attention on the question why nonprofit provision rather than government provision; for asking only why non-profits emerge to provide goods which are generally provided by governments. These critics note that in many industries non-profit organisations provide services similar to those provided by for-profit firms. What needs to be explained is why non-profits exist in industries where services are or can be readily provided by supposedly more efficient forprofit firms. To answer this, Henry Hansmann has developed the theory of contract failure. He argues that under some circumstances, consumers will prefer non-profit providers over for-profit providers because they do not trust the for-profit provider. One 
set of circumstances where this arises are where services are complex and difficult to evaluate and where the cost to the consumer of changing provider are higher. Under these circumstances, the consumer will prefer an organisation which is constrained from distributing any surplus to its owners as a protection against exploitation. A similar preference for non-profit providers will occur where people wish to help others, but cannot, or do not wish to provide assistance directly to identified individuals. Under these circumstances, they will make donations to an intermediary organisation; sensibly, they will seek one constrained from making a profit as an assurance that the bulk of their benevolence will reach its object (Hansmann, 1986).

Hansmann's theory of contract failure also explains why it is non-profit organisations become the providers of public goods when they are not provided by governments. Public goods are characterised by non-rival consumption which means they can be consumed by non-payers, the so-called free-riders. Governments overcome the problem of free-riders by funding public goods through general taxation or through licensing consumers (as with radio and television licences in some countries). Where a government does not provide public goods, only some form of donated funding will enable services to be provided. Under these circumstances, non-profit providers will be trusted rather than for-profits to use the donations to provide the service rather than for personal enrichment. Once again, it is a question of means and ends. Trust is more sensibly given to people exclusively committed to providing a service rather than to making a profit by providing a service. The non-profit form of organisation is a way of distinguishing one set of motives from another. People whose exclusive commitment is to providing a service will happily utilise a non-profit form as they do not wish to make a profit; those whose goal is to make a profit cannot easily (or honestly) use such a form.

Hansmann refers to the inevitability that donatively financed organisations will be nonprofit to help explain why organisations providing high culture performing arts and museums will be non-profit. He argues that because demand for these services is relatively low compared to the cost of their production, there is no single ticket price that would cover the costs of production. Some form of voluntary price discrimination is required to ensure that those with a high level of demand (and a capacity to pay a high price) pay more than those with a low level of demand or little capacity to pay. Fortunately demand is high among the social elite, most of whom are wealthy and are prepared to participate in a system of voluntary price discrimination in the form of donations. Because provision depends on donations, providers will be non-profit, rather than for-profit (Hansmann, 1981). That provision might be by a government organisation is not considered, probably because it rarely is in the United States. That it might be does not invalidate Hansmann's general point which is to show why provision will not be forprofit.

Hansmann has also investigated the reason for the significant presence of the mutual form of organisation in the provision of insurance. He explains this as another example of market failure; indeed the form of contract failure that characterises the life insurance industry is similar to that which characterises the provision of other complex, hard to evaluate services (Hansmann, 1985). However, Hansmann does not consider that mutual insurance organisations are non-profit as they are not prohibited from distributing their profits to their members. Yet he acknowledges that they are clearly distinct from forprofit organisations as well. Hansmann defines "non-profit" in the manner of the US Tax Code. This paper uses "non-profit" to describe all forms of organised activity that are neither government nor for-profit. 
The problem with all the theories considered above, as Estelle James has noted in an important article, is that they seek to explain the existence of non-profit organisations as a function of demand for their services. They do not directly address the question of why the organisations were formed and why they were formed as non-profit organisations. On its own, the existence of demand does not necessarily bring forth a supply. In conventional economic theory, the emergence of a supply of a service requires an entrepreneur: that is, someone who recognises (or believes) that there is a demand for a particular sort of service and can raise the capital and other organisational requisites to provide the service to meet that demand. James has developed a supply-side dimension to Weisbrod's demand side theories. She proposes that it is generally people associated with organised religion or some other "ideological" organisation who have the motivation (or intensity of preference) and, most importantly, access to capital via the wealth of the religious denomination, who will start non-profit organisations. She adduces some comparative evidence that shows that private schools are likely to be more numerous in countries with high levels of religious heterogeneity (James, 1987).

In summary, according to the common explanations, non-profit organisations are likely to have a significant presence in democratic societies characterised by a high level of religious (or ethnic) heterogeneity and/or where demand cannot be satisfied by public providers or, because of the complex nature of the service, by for-profit providers.

Several points can be made about these common explanations or theories. The first is that, like most economic theories, they rely on simplified models of individual behaviour. Many will find that these models entail assumptions that distort rather than simplify the way the world works. An example would be Weisbrod's median voter model of the relationship between voting behaviour and government policy. The second is that they have no predictive power. Rather, they are tightly specified generalisations that serve to explain existing patterns of arrangements (mostly in the United States). That is, whilst they can explain a number of instances, they cannot specify in advance whether non-profit organisations will be found or not (Ware, 1989). The third is that they are culturally and temporally bound. They presume the existence of clearly distinguished public and private realms and within the latter, of private firms. These distinctions, like the firm, are largely the product of nineteenth century Europe and America. Yet many important organisations that we recognise as being non-profit originated in earlier times.

Related to the above is that the common theories are concerned only with service providing organisations, and not those that are formed to facilitate an activity (e.g. a sporting club) or to advance a cause (e.g. Greenpeace). In some studies, the field is deliberately limited by referring only to organisations given particular forms of tax concessions in a particular country.

The fifth point is that the supply side theory is not adequately developed. Little attention is paid to the creation of organisations. Those who focus on the demand side appear to presume that entrepreneurs, in establishing an organisation to provide a service, consciously choose between the for-profit and non-profit forms, or that both forms coexist in the early years of the service but only one prospers (because of the special character of the demand). This may be true for some, but there is no evidence that this is the way all or most services come to be provided. 
Nonetheless, a glance at Australia suggests at least a superficial confirmation of some of the common explanations. Australia has, and has had for over a century, a large and important non-profit sector. It has also had a heterogenous population and democratic forms of government. However, a closer examination reveals a more complex picture, some of which does not seem to be explainable by the most commonly used theories. Before exploring this, it is necessary to provide a quick sketch of the history of non-profit forms of organisation in Australia.

\section{THE HISTORY OF NON-PROFIT ORGANISATIONS IN AUSTRALIA - AN OVERVIEW}

\section{8-1860s: From Convicts to Gold}

European settlement in Australia began in 1788 with the establishment of a British convict colony at Sydney Cove. With increasing numbers of free immigrants, the colony gradually lost its gaol-like character and during the next fifty years five other colonies were established in Tasmania and at other parts of the Australian mainland. The discovery of gold in New South Wales and Victoria in the early 1850s greatly boosted the population and wealth and accelerated the development of a highly urbanised fragment of British society which the six colonies had become by the 1870s. The Anglican church was the first nonprofit organisation present in the colony. Other religious denominations followed, opposed by the Anglicans but generally tolerated by government. All denominations moved to establish a system of schools, replacing a few small for-profit providers, and institutions to care for the poor, particularly orphans. Independently of the churches, members of the social elite established institutions for the relief of poverty and one or two schools for the education of their own children. All these efforts received some support from the government. In the small but growing colonial society there were few other organised voluntary endeavours that were able to maintain themselves for more than a few months. Non-profit organisations depended on the resources of religious denominations or on the confidence and relative wealth of the colonial elite (to say nothing of the financial support from government) if they were to survive.

\section{0-1914: The Growth of a Non-profit Society}

During this half century the Australian colonies (after federation in 1901, states), in particular their capital cities, grew in population and wealth. By the late $1880 \mathrm{~s}$, the Australian colonies, with a population of 3 million people, had the highest per capita income in the world. (After that they began slowly to decline in relative terms, but that did not emerge as a problem until the late 20th century.) This period saw a flourishing of non-profit activity in a variety of fields and industries. In particular, it saw the growth of mutual benefit organisations. Friendly societies or lodges contracted with doctors to provide medical services and insured against loss of income if illness prevented work. They also paid for a respectable funeral in the case of death. In some other cases they provided a short-term unemployment insurance (Green and Cromwell, 1984). Other mutual organisations emerged to provide life insurance and building societies assisted low and middle income people save for and purchase housing. The last two examples experienced for-profit competition but were maintained by the familiarity with and commitment that many people had towards the mutual form of organisation. More than half the adult male population belonged to lodges of some kind. Trades unions, another form of mutual benefit organisation, also flourished. In response to the growth of unions and the deep-set political issue of tariff protection, many business associations were also formed. From the mid-century, associations advancing technical education and practical 
science, such as acclimatisation societies and mechanics institutes flourished. During the 1880 s a number of professional associations emerged as well. The organisation of sporting and other recreation activities proceeded apace. Some mutual non-profit organisations were created to give expression to particular values that mixed religion and ethnic identity, often in a way that involved overt hostility towards others in the colonies. These sometimes were used as the basis of organised attempts to change government policy. They were closely tied to either evangelical protestantism or the Catholic church. Around the turn of the century, modern political parties such as the Labor party were formed to seek the election of their members to parliament.

Religious denominations remained a vital source of non-profit endeavour. In the 1860 s and '70s, colonial governments moved to take over the denominational schools which they subsidised, arguing that a single system of government schools was a more efficient way to spread educational opportunity to country areas and was a guard against the emergence of social divisions based on denominational differences. The hierarchy of the Catholic church held out against this and retained and expanded their school system without government assistance (Gregory, 1973; Lyons, 1972). Prompted by new theories about the best way of caring for orphans and deserted children, governments moved to take over a number of previously independent charities that provided congregate care for such children in order to close them down and place their inmates in foster care. However, church-based initiatives led to a flourishing of new children's homes, along with other welfare endeavours (Dickey, 1987; O’Brien, 1988). Non-profit hospitals, many of them church-based, emerged alongside others that were directly administered by government. They received increasing levels of government support and by the new century were referred to as public hospitals. Whilst church schools existed to provide a distinct religious education for children of their particular denomination, church-run hospitals applied no religious tests. Although church-based welfare organisations were sometimes started to remove the possibility of other denominations proselytising amongst the orphaned and the poor of their denomination, in practice, religious tests were rarely applied. Significantly, apart from their own exclusive social clubs, the elite of colonial society generally did not involve themselves in the creation of non-sacramental, non-profit organisations. This contrasts with the United States at this time.

\section{0s - 1960s Business Nonprofits in a Conservative Society}

The first world war had a dramatic impact upon Australia. Nearly $40 \%$ of these eligible enlisted; most saw active service and of these, seventy percent were killed or wounded, the highest casualty rate of any of the allied forces. The country was deeply divided over the issue of conscription. Australia emerged from the war shorn of its confidence and its radicalism. The depression of the 1930 s created over $30 \%$ unemployment. Although Australia's economy depended on the export of primary produce, a nascent manufacturing industry established in the earlier period developed behind significant levels of tariff protection and with the technological stimulation of two world wars.

Early in the period, the main non-profit initiatives came from the growing business and professional classes. The most common initiative was the establishment of what were generally called community service clubs such as Rotary, Lions and Apex. These modernised the old friendly societies and masonic lodges by cutting down the ritual and mixed mutual benefit with acts of community service such as providing neighbourhood parks or initiating new organisations for particular disadvantaged groups such as crippled children. Starting in the 1920 s but retaining a momentum until the 1950s, non-profit 
organisations such as progress associations and recreation clubs emerged in many smaller country towns to provide the fabric of facilities and services that urban Australians considered essential components of life. In New South Wales, in the late 1940s the state government gave to non-profit recreation clubs the exclusive right to operate poker machines, which provided a massive cash flow to clubs (and to the government) and which transformed those clubs into major leisure centres.

Although building societies were given a new lease of life with government support and came to dominate housing finance between the 1940 s and 1970 s, other mutual benefit organisations lost their hold, sometimes as a result of successful opposition (such as that mounted by the medical profession against friendly societies). The 1950s and 1960s saw the emergence of parent-run organisations providing services to children with various forms of disability. It also saw the Commonwealth government which, with its exclusive right to tax income now raised considerably more revenue that state governments, emerge as a significant source of subsidies for certain health and community services and, in the $1960 \mathrm{~s}$, for school education, providing government assistance to private or non-profit schools for the first time since the 1870 s.

\section{Late 1960s - 1980s: The Flourishing of Community Endeavours}

The late 1960s, 1970s and 1980s saw the decline of Australian manufacturing industry and the rapid growth of the service sector; it also saw a far higher percentage of young Australians completing post-secondary education. The first wave of this university educated elite swelled the ranks of the counter-culture and the Vietnam generation in the late 1960s and early 1970s. Rejecting bureaucracy, whether public or private, hostile towards the professions and institutions such as religion and the family and with the active assistance of some of their number who were transforming governments from within, this generation formed thousands of new non-profit organisations to provide health services, housing, community development, aged care, disability services, child care, schools, culture, recreation and so on. The term community was frequently invoked to describe these endeavours (Lyons, 1985). Part of this movement, and mixing service provision with advocacy, were self-help groups organising around the issue of rights: for women, for Aborigines, for people with disabilities, for the aged, for gays. From the mid-1980s deregulated financial markets created competition that finally destroyed most non-profit financial organisations. Television and sponsorship combined to feed vast amounts of money into certain sports, cricket, football, tennis and golf in particular, making their players highly paid professionals and forcing the nonprofit organisations that ran those sports to professionalise their management. Similar pressures were at work in other large nonprofit organisations during this period. As many became multi-million dollar enterprises they had to adopt many of the management practices developed by large business organisations before them. Usually, these new management approaches were married to governance structures that reflected the organisation's origins.

\section{SEVEN CASE STUDIES OF NON-PROFIT GROWTH AND DEVELOPMENT}

The preceding overview is necessary to provide a background to the more detailed case studies that follow. Each study briefly outlines the development of a class (or group) of non-profit organisations. Each case would have to be included in any comprehensive history of non-profit endeavour in Australia. Each study seeks to answer the question of why that class of non-profit organisation emerged and why they became significant components of their particular industry. In two cases it looks at why they declined. In 
each case, the explanatory adequacy of what was earlier described as the conventional theory will be tested.

\section{Case 1: Private or Non-profit Schools}

When Australia was first settled by Europeans, schooling was seen as a church responsibility, although some private entrepreneurs also ran schools for a (small) profit. Not surprisingly, it was the religious denominations that began schools although they needed assistance from colonial governments to do so (Fogarty, 1957; Barcan, 1980). By mid-nineteenth century though, dominant opinion in the colonies held that governments should operate a single primary school system in which all children should be educated. These schools should teach the basic tenets of Christianity; it was hoped that a single system of schools would discourage the growth of religious differences and thus encourage social harmony. It would also be a more efficient way of ensuring that schools were available for every colonial child. The first step was to establish a system of government schools to operate in parallel with denominational schools. Several decades later, as opinion hardened, government aid for denominational schools was ended and most denominational schools passed into the new state system. The exceptions were denominational secondary schools (few in number and educating the children of the social elite) and Catholic schools.

In contrast to the Protestant denominations, the Catholic bishops maintained and expanded their separate system of schools. In this they were supported by a majority of their congregation though they were opposed by some. Along with Catholic churches, Catholic schools became the focal point for a separate Catholic sub-culture which helped generate and sustain other Catholic non-profit endeavours (Lyons, 1972). This separate identity helped tie Catholic support to the Labor Party during the first decade of the twentieth century. Despite this support, the Labor Party never provided the bishops with the state aid for their schools which they frequently demanded, largely because other major components of the Labor Party were strongly opposed to state aid. Most Catholics active in the Labor Party did not press for it. Nonetheless, the Catholic bishops often called for a restoration of state aid but were unsuccessful until the 1960s when a Federal Liberal Party government, seeing an opportunity to pry some Catholic support away from the Labor Party, began to subsidise private schools ( $80 \%$ of which were Catholic schools). Since then government aid has been significantly expanded and targeted so that the poorest schools in poorer areas received most support. Despite this government support there has only been a small increase in the percentage of schools which are private, mostly started by evangelical Protestant groups.

Thus the history of non-profit schools in Australia moves through three phases. In the beginning, apart from a few short-lived for-profit establishments, non-profit schools were the only schools but they relied on government financial aid. Colonial governments were interested only in ensuring the provision of schools and were not prepared to operate schools of its own. In the next stage, governments began running their own schools in parallel with the denominational schools and then moved to take over existing, subsidised schools from those denominations. The Catholic church resisted this and operated a separate system for almost a century until the third stage, with governments again began providing subsidies to private schools.

The shift from non-profit to government provision of schooling seems to accord with the historical movement proposed by Weisbrod as a consequence of his median voter theory, 
but the pattern of events is not well explained by his theory. Indeed, the fact that the exclusively non-profit provision received heavy government subsidies would force Weisbrod to define the provision as government rather than non-profit. But assuming that it was non-profit, explanation of the change to government provision requires exogenous as well as endogenous variables. Heavy government subsidy of non-government provision did lead to a search for more efficient means of supply. This a government run system provided. The shift roughly coincided with a move to male suffrage, but since taxes were all indirect, it is hard to see how the increase in potential "demand" affected government decisions. (This exemplifies the a-historicism of the economic model of voter and government behaviour adopted by Weisbrod.) More importantly, the shift to a government system of education was both inspired and enabled by the growth of the antisectarian strand of colonial liberalism. The liberals' vision of a harmonious society could only be achieved by replacing separate denominational systems with a single system, which had to be government run. This was clearly an exogenous variable.

The subsequent existence in Australia of a large, mainly Catholic private school sector seems to support the Weisbrod/James theory of differentiated taste arising from religious heterogeneity and the importance of religion as a source of motivation and resources for the formation of non-profit organisations. But on closer inspection, while the theory is apparently confirmed by the outcome, it does not provide a sufficient explanation of those events which led to the outcome. Given that all major denominations had been subsidised by the government for decades, why was it only the Catholic church which stood out against the government's determination to support only its own system of schools? Given the strength of institutional immutability, it is a least as important to ask why the Protestant churches agreed to the changes and gave up their schools rather than why the Catholic church refused to change. To assume that it was because Catholics were discriminated against by a majority (but undifferentiated) Protestant population is to give undue weight to Catholic myth-makers. At all events, it is not a question James can easily answer.

The answer to this question lies in colonial and world history. The opinion that urged a single system of government schools identified itself as colonial liberalism. One strand sought to confine clergymen to sacramental and preaching roles. It wanted them and the churches to play a less active part in political and cultural affairs. This view was shared by many leading Protestant and Catholic laity. However, in the strongly hierarchical Catholic church, the laity has less capacity to shape Church policy than in the other churches (Lyons, 1972). Even the Anglican church had a synodical form of governance. Some of the Protestant clergy wanted to retain their separate denominational schools but were worn down by pressure of lay opinion and the recognition that they would not have the resources to sustain them. By contrast, the Catholic bishops were particularly conscious of being part of an international organisation. Their orders came from Rome. Their way of viewing the colonial world was formed in Rome and in Ireland and to them the tenets of colonial liberalism were anathema (Molony, 1969). Fortunately for them, most of the Catholic laity were of recent Irish origin and were easily persuaded to accept the bishops' view that State schools which taught a form of common Christianity were really designed to weaken the Catholic faith. They were readily persuaded to financially support the maintenance and expansion of an independent Catholic school system.

The third phase, where a government restores state support for denominational schools is explicable in terms of the Liberal party seeking to widen its basis of support. It entailed 
seeking support from Catholics who were marginal Labor voters. To a certain extent it was successful, but eventually it was matched by Labor. In terms of the Weisbrod/James theory of differentiated demand, the change in government policy seems to reflect a reduction in the degree of differentiation. But it is this in a strange way. The Liberal government's policy reflected a recognition that electoral hostility towards Catholic separateness, manifested in Catholic claims for state aid for Catholic schools, was no longer important. This represents a reduction in differentiation, but not by the group which stood out, but rather by the majority who decided no longer to object to that.

Overall, then, the case of non-profit schools is only partly explained by the theories of Weisbrod and James.

\section{Case 2: Friendly Societies}

Friendly societies flourished in Australia from the 1860s until the 1930s. Modelled on masonic lodges, themselves drawing features from medieval guilds, they combined regular meetings and rituals with the organised provision of a variety of services. Australian friendly societies largely began as branches of British societies, brought to the colony by immigrants from Britain, though others, such as the Australian Natives Association were homegrown. They bore exotic names: Ancient Order of Foresters, Ancient Order of Druids, Manchester Order of Oddfellows, but their local branches enrolled almost a majority of Australian menfolk (though not all were regular attenders at lodge meetings). They provided rituals for affirming group solidarity along with services, the most important of which were funeral benefits and health insurance. Their entry into the insurance field attracted government concern that their plans might not be actuarially sound. This in turn created tensions within each friendly society between local lodges which emphasised solidarity and were little concerned with long term financial viability and their head offices which were. To ensure availability of medical treatment for their members, the lodges sought to contract medical practitioners to take responsibility for treating their members. Doctors were reimbursed according to a chart of fees set by the lodge or on a capitation basis. The medical profession objected and eventually persuaded the Commonwealth government, in 1951, to legislate for fee-for-service medicine where fees were set by the government and medical bodies co-operatively (Green and Cromwell, 1984). Many friendly societies then became health insurance organisations. Some later branched out into other activities such as aged care. By then they had long ceased to meet as local lodges and had become quite highly centralised bodies.

Economic theories of non-profit organisations are uneasy with all forms of mutual benefit organisation. They prefer organisations where the members and the management are not part of the set of beneficiaries of the organisation. Yet, in Australia at least, mutual benefit organisations have done far more in overcoming inequality in the distribution of resources than all the more conventional, donative, types of organisations favoured by most economists. Friendly societies emerged at the beginning of the social turmoil called the Industrial Revolution. They represented efforts by the respectable lower orders to adapt old organisational forms to new challenges. They came to Australia with migrants from those classes and were adapted to meet Australian conditions. They were the product of "non-profit entrepreneurs" who recreated in the new land important institutions from the old. They met a demand but in the sense they, or the institutional tradition they represented, created the possibility of a particular service and thus created a demand. Their combination of service provision and sociability is particularly important. When for-profit forms emerged to provide similar services, the lodges held their attraction for at 
least two more generations because they provided rituals and opportunities for socialising that were satisfying to many and because their members could feel that had some involvement in and thus control over the services that their lodges provided.

In short, the common economic theories do not attempt to explain such phenomena.

Hansmann comes closest, arguing that mutual insurance organisations are successful because they are more readily trusted than for-profits (Hansmann, 1985). That might help explain the strength of the lodges but not their origins. Friendly societies pioneered certain forms of service provision. There was no question of their originators consciously choosing a non-profit or a for-profit form. Such distinctions did not then exist as they do today. An adequate explanation of the origins and growth of friendly societies must be grounded in social and institutional as well as economic histories.

\section{Case 3: The Loyal Orange Institution}

Friendly societies were distinguished from other forms of masonic-type organisations by their emphasis on providing certain services in addition to their rituals and their local lodge type of structure. Other masonic types of organisations were formed to express particular and maintain cultural values. These were often far from "friendly". One such group of organisations was the Loyal Orange Institution or orange lodges, which had considerable growth in Australia in the late nineteenth century, at one time enrolling 1 in 5 of those eligible to join (Lyons, 1972). Orange lodges were built around rituals with a strong anti-Catholic (and anti-Irish/Catholic) orientation. Publicly, Orangemen professed to fear that Catholics were becoming too numerous and too powerful. Their fears were fuelled by examples of Catholic separateness (or sectarianism), such as the insistence by the Catholic bishops to retain their separate Catholic school system. Their leadership was closely intertwined with the evangelical wings of most Protestant denominations. For their membership they drew largely from the lower orders. Mostly, they were ignored, but sometimes deplored, by the colonial elite. They began their own service organisations, such as friendly societies and building societies but they declined slowly from the 1890 s onwards, particularly as politics became organised along class lines.

The Loyal Orange Institution is an important example of non-profit endeavour, but its bigotry places it on the dark side of the non-profit sector. Nonetheless, its existence must be recognised.

Conventional theories of the origins and growth of non-profit organisations assume that organisations exist to provide a tangible service. They say nothing that can help explain the origin and growth of non-profit organisations such as orange lodges.

\section{Case 4: Legacy}

Legacy is a large federation of non-profit welfare organisations that provide advice, financial support and other services to the dependants of the deceased ex-servicemen. Its members, "legatees", are men who have served in a theatre of war with the armed forces of Australia or its allies. When it began after the first world war, it was primarily to help the children of soldiers killed in the war; the second world war reaffirmed that aim but subsequently its clientele gradually changed. Now its members are mostly in their sixties and its clients are mostly elderly women. In the absence of another major conflict involving Australia's armed forces, Legacy will cease to exist in another 20 years. At its peak in the late 1960 s, operating through 45 clubs, Legacy was one of the largest welfare endeavours in Australia. 
Legacy's origins lie with a group of young ex-army officers who met in Melbourne in 1923 to form a Rotary type of club for ex-servicemen in business and the professions. Its more idealistic members were dissatisfied with that selfish object and determined that their purpose should be to help the children and widows of their "mates" who had been killed in the war. Clubs formed around this vision were quickly established in other state capitals and other cities and towns. An element of mutuality and sociality was retained, as members met at weekly luncheons, but the real work of "legatees" was advising the widows and children of deceased ex-servicemen and providing financial support where necessary. Finances were raised by public appeals (Lyons, 1978).

The first world war dramatically affected Australia, none more so than the survivors of its armed forces who returned halfway around the world to a country that was deeply divided and which some had not seen for four years. Many were soon disillusioned. They felt a race apart and believed that their fellow countrymen did not sufficiently recognise what they had been through and did not seek to accord to them the leadership roles for which they believed they had qualified. Legacy grew out of this ex-servicemen's culture. A new Commonwealth government department had been formed to assist returned soldiers and their dependent with housing and financial support. Legacy worked closely with this department but provided a personalised service (a form of voluntary case work) which the department could not provide.

At one level, Legacy is an example of Weisbrod's median voter theory. Legacy provided more than the government could afford to provide; the experience of war created a sense of separateness and an intensity of feeling to prompt its foundation and rapid spread. But such an explanation is only partial. It does not account for how the motivation was created and it does not recognise the importance of the club form, the luncheon and associated rituals to maintaining membership and thus the supply of services Legacy provided. It does not adequately account for the altruism that prompted the original founders of Legacy to eschew the businessmen's club they had initially sought to found and create a primarily service oriented organisation.

\section{Case 5: Building Societies}

Non-profit building societies were important sources of housing finance in Australia in the 1880s. Their success spawned many for-profit institutions and most collapsed in the depression of the $1890 \mathrm{~s}$. A few re-emerged in the twentieth century but almost all of these were destroyed in the 1930s depression. In the mid 1930s housing finance was hard to obtain; banks required a borrower to have saved an equivalent to the size of the loan sought. This prompted several senior New South Wales public servants to look for ways of reviving housing market. They came upon several terminating building societies still operating in the small country town of Mudgee. Unlike the usual terminating society which took subscriptions from its members and balloted a loan every time the pool of subscriptions became large enough, the Mudgee model, which had been operating since the 1880s, added an external source of finance. Those who had set up each society had persuaded a local bank to lend the society a sufficient sum to enable each subscriber (usually 20 or 30 people) to obtain a suitable loan at the beginning, so that their subscriptions were used to pay off the loan. With some arm twisting, those senior public servants found they could persuade some Sydney based banks to put up loan money provided the government guaranteed the loan and they then set about encouraging a few of their contacts to establish local terminating building societies along these lines. To do the organising and, in effect, to screen potential borrowers, they chose small business men 
active in the affairs of their local suburbs and trade union officials in large work sites. These men then set about screening suitable members. Both types of men chosen to initiate the new building societies were familiar with the mutual benefit type of organisation. They were also well placed to assess the reliability of borrowers, who, in effect, had to join a terminating building society to be able to access a loan. The scheme worked well; those involved in setting up the original societies established more. The model was adopted by other state governments (Lyons, 1988).

In the late 1940s, terminating building societies were the largest single source of housing finance. Their success lead the banks to conclude that they could afford to make far more generous loans directly and in so doing to build a wider customer base. Banks no longer lent to the terminating societies so they in turn persuaded the Commonwealth government to provide them with new loan funds though those monies then had to go exclusively to people on low incomes. As well as tapping this new source of funds, the building society protagonists took advantage of the burgeoning post-war economy and established permanent building societies. These raised deposits (ostensibly in the form of share purchases) from the public (who thus became members) and loaned them out to members who needed housing loans. Despite the riskiness inherent in "borrowing short and lending long", in a growing economy the new building societies prospered and by the 1970s provided as much housing finance as did the banks. Competition created pressures towards amalgamation of building societies and many local societies became part of larger state-wide bodies. The 1980s saw deregulation of financial markets and greater competition from the banks. Most building societies converted to for-profit banks, raising additional capital by conventional share issue, or were taken over by existing banks.

Building societies, both terminating and permanent, are mutual benefit organisations. They can trace their origins back to friendly societies but by the late nineteenth century most had disbanded the rituals and regular meetings of members. Their managers were usually not beneficiaries of loans. Terminating societies were successful at raising funds because they had a government guarantee. They were successful lenders because of the close knowledge they had of their borrowers and the sense of mutual dependency they created amongst their members. They demonstrated that the market for housing loans was much larger than the for-profit providers believed. When the banks moved to provide the finance directly, new terminating building societies obtained funds from the government and became part of government housing policy. Meanwhile, utilising their local links, building society champions were able successfully to establish permanent building societies which directly and successfully competed with the banks. Again, a capacity to utilise local or regional identification and the trust which that generated created their success. However their success in turn generated pressures for growth and amalgamation which mean that the surviving largest societies mostly lost their local links and some of the trust and identification which contributed to their success. In a more competitive environment they were no longer to able to compete successfully with the much larger banks.

Little of the popular explanations for the origins and growth of non-profit organisations seems to fit the building societies case. Their origins, which lie in the entrepreneurial efforts of public servants, working with community leaders already familiar with mutual benefit types of organisations, are not readily explained by any of the popular theories.

The origin and growth of the terminating societies provides a nice example of market failure, but the failure is that of the for-profit banks which would not respond to the 
demand for housing finance for low to middle income earners because they believed them to be too great a risk. Only when a non-profit intermediary was created to screen borrowers and their loans guaranteed by the government, would they venture their funds. But this is not the form of market failure of which Hansmann writes. Neither is the success of the permanent building societies explicable in the terms that Hansmann uses to explain the success of mutual insurance companies. The contract between member/lender or member/borrower and the building society is not a complex one. Their success seems to lie in a number of factors: their origins in the successful terminating societies; their ability to exploit local identity and the sense of trust that the mutual form of organisation encouraged; the distrust, even hostility, with which the banks were viewed by many Australians in the aftermath of depression foreclosures. The last factor cannot be overemphasised. When the banks decided to seek a broad customer base in the early $1950 \mathrm{~s}$, because of that distrust and the effective competition from the permanent building societies, it took almost a generation before they were completely successful. The permanent building societies had a good start, but they were in a long distance race which they could not win.

\section{Case 6: Child Care}

In Australia, the organised provision of child care began in the late nineteenth century. A few day nurseries and kindergartens were begun in working class areas of the capital cities by members of the social elite. Kindergartens concentrated on preparing children in "slum" areas for school, while day nurseries provided care for children of working mothers. Until the 1940's only the former expanded. During the second world war, many women with young children were recruited by industry and for-profit child care centres were established in many suburbs to meet their needs. A few of these continued after the war, mostly in working class suburbs (Brennan and O'Donnell, 1986).

In the early 1970's, a newly elected Labor government promised a massive expansion of preschool education. However, the newly re-formed feminist movement, particularly the Women's Electoral Lobby, pressured the government to change its policy and to fund a large expansion of long day child care. The object of this new policy was no longer the preschool education of working class children, but to help women with young children to return to the workforce. The model proposed by the women's movement was of child care centres run by community or non-profit groups, mainly formed from parents or prospective parents, but with the government meeting capital costs and providing heavy recurrent subsidies to keep fees within reasonable limits. Most of these advocating this policy were tertiary educated women in middle class suburbs and it was they who were initially its greatest beneficiaries. Over time, however, the administration of the Childrens' Services Programme has changed so that government subsidies (or fee relief) now goes largely to low income families at levels proportionate to their family incomes. The 1980's in particular saw a large increase in child care places. Two thirds of these were in government centres and family day care schemes: one third in for-profit centres. Nonetheless, supply still lags well behind demand (Lyons, 1989). Only in 1991 did children attending for-profit child care centres become eligible for government fee relief.

Thus it was that from the mid 1970's, the Commonwealth government, through its Children's Services Programme, stimulated the creation of a large number of non-profit organisations. It was prompted to do so by the newly re-emerging feminist or women's movement which developed a powerful rhetorical justification for child care as a woman's right. (In our more economically stringent times, it is now justified as a labour market 
programme.) The huge expansion of non-profit child care is one of the main community endeavours that proliferated in the late 1960's and 1970's. This expansion of supply by non-profits, with government support, could be constructed as an example of market failure. Despite burgeoning demand, commercial operators were unable or unwilling to expand - a case of "entrepreneurial failure". The successful entrepreneurs in this case were strongly motivated activists from the women's movement, both within and without the bureaucracy. There is some evidence that where for-profit and non-profit child care centres compete, the cost structure of the non-profits is markedly higher because more experienced staff are employed, but that consumers prefer non-profit provision (Lyons, 1989). The latter appears to support Hansmann's theory of contract failure.

But this is a demand-side explanation. A "supply-side" explanation would recognise that the basis for expansion was government grants, won by the lobbying efforts of the women's movement. Full explanations for the expansion of non-profit child care in Australia must lie in the realm of politics and at a deeper level, in understanding the (re) emergence at that time of the women's movement.

\section{Case 7: Museums}

A final case is that of natural history and art museums. These are a little like the case of the dog that did not bark. As noted above, Hansmann has explained why museums in the United States are non-profit. However, in Australia the major museums in each capital city are government bodies. They are governed by trustees appointed by the government and their staff are employed as public servants. Apart from the Australian Museum (of natural history) begun in Sydney in the 1820's, they all were commenced in the last four decades of the 19 th century. In all cases members of the colonial elite took the initiative but with a view to establishing the museums as a government responsibility. All soon were. That this happened is not surprising. Invariably some of the elite involved in a museum's establishment were members of the government. More importantly, it seemed perfectly acceptable to most colonial parliamentarians and to their electorates that such institutions should be a government responsibility. Such bodies were seen to have important educational benefits; natural history and technological museums were seen as benefiting colonial industry as well (Strahan, 1979; Anon., 1963). In addition, museums were part of the cultural landscape of the larger cities of Great Britain from whence most colonists came and to which most still refered as "home".

All the museums, but particularly the art museums (or art galleries as they were called in Australia) depended heavily on private donations and bequests to build up their collections (Anon., 1963). To that extent they probably differ only marginally from the major United States museums in the sources of their revenue. However, in Australia they were clearly government organisations from their beginning. Hansmann's arguments may explain why such organisations take a non-profit form if they are not public, but they cannot specify the characteristics of a society (and polity) where such bodies will not be public institutions. A society where large museums are non-profit rather than government in ownership is the exception, not the rule. 


\section{CONCLUSIONS}

The preceding cases suggest that the commonly used economists' explanations for the origin and growth of non-profit organisations cannot adequately account for important Australian developments. These explanations have been developed to deal with a limited set of organisations in a particular culture, at a particular historical period. Thus, for example, they do not, or do not adequately, address the origins and success of mutual benefit types of organisations, particularly their origins. To do this would seem to require borrowing from sociological or anthropological theory. As well, they fail to take account of changes in the expectations held of government over the past 200 years and of the different ways by which governments might become involved with non-profit organisations. Thus, as the private schools case shows, a theory that explains why nonprofits emerged to provide some collective goods in addition to those provided by governments cannot explain circumstances where non-profits are the sole providers of these goods, but are supported by governments that wish to see goods provided but do not believe it proper for government to be a provider. The building society case shows government employees as entrepreneurs but for non-profit activity; the child care case shows non-profit "entrepreneurs" directing their efforts at winning government support for an expansion of non-profit service provision.

In part, the inadequacy of the common explanations is a consequence of their focussing largely on the demand side. By and large, it is in explaining the growth of particular sets of non-profits that they work best. But even here, their explanations are only partial. Hansmann rightly points to the importance to consumers of being able to trust an organisation, but does not identify all the various ways by which such trust might be generated. Several of the cases concerned mutual benefit organisations that relied on a local lodge structure. It was this form that helped create trust; in addition, it was a form of organisation with which many people in the nineteenth and early twentieth century were familiar.

The popular explanations are weakest in explaining the supply of non-profit services. They are generally not very helpful in explaining why non-profit organisations begin in a particular industry. James is right to point to the strong motivation and the availability of capital as two factors which will always be present, but she does not provide a full listing of how such factors might be manifested. Certainly, religious denominations were important sources of motivation and capital. But so too was economic necessity, as the friendly societies' case shows, and so too was the need to affirm identity and publicly express values through organisation as the Loyal Orange Institution case demonstrates. In these cases, it was the mutual benefit form of organisation, already institutionalised by the early nineteenth century, that provided through membership fees, the source of any needed capital.

Altruism, the desire to help others without any expectation of reciprocation, is also an important motive behind the formation of some non-profits. It helped create and build Legacy. However, it should be recognised that altruism is shaped by culture and circumstance and only rarely will it drive people to organise. On its own, altruism is not a sufficient explanation for the formation of a particular non-profit organisation or group of organisations. 
All in all, an historical account of the origins and growth of non-profit organisations has to be just that. It can borrow insights from other social sciences but cannot become subservient to any of them. An interesting question is whether an adequate account of the origins and growth of non-profit organisations can be other than an historical one. 


\section{REFERENCES}

Anon, (1963), "Art Galleries", The Australian Encyclopaedia, Vol 1, The Grolier Society, Sydney, pp 253-260.

Barcan, Alan (1980), A History of Australian Education, Oxford U.P., Melbourne.

Brennan, Deborah and O'Donnell, Carol (1986), Caring for Australia's Children. Political and Industrial Issues in Child Care, Allen and Unwin, Sydney

Dickey, Brian (1987), No Charity There. A Short History of Social Welfare in Australia, Second Edition, Allen and Unwin, North Sydney.

Fogarty, Ronald (1956), Catholic Education in Australia 1806-1950, 2 vols, Melbourne University Press, Melbourne.

Gregory, J. S. (1973) Church and State, Cassell Australia, Melbourne.

Green, David and Cromwell, Lawrence (1984), Mutual Aid or Welfare State. Australia's Friendly Societies. George Allen and Unwin, North Sydney.

Hall, Peter Dobkin (1987), "A Historical Overview of the Private Nonprofit Sector", Walter W Powell (ed), The Nonprofit Sector, A Research Handbook, Yale University Press, New Haven.

Hansmann, Henry (1981), "Nonprofit Enterprise in the Performing Arts", Bell Journal of Econmics, 12, pp 34-61.

Hansmann, Henry (1985), "The Organisation of Insurance Companies: Mutual Versus Stock", Journal of Law, Economics, and Organisation, 1(1), 125153.

Hansmann, Henry (1986), "The Role of Nonprofit Enterprise", Susan RoseAckerman (ed), The Economics of Nonprofit Institutions. Studies in Structure and Policy, Oxford University Press, New York.

Hansmann, Henry (1987), "Economic Theories of Nonprofit Organisation", Walter W Powell (ed), The Nonprofit Sector. A Research Handbook, Yale University Press, New Haven.

James Estelle (1987), "The Nonprofit Sector in Comparative Perspective", Walter W Powell (ed), The Nonprofit Sector. A Research Handbook, Yale University Press, New Haven.

Lyons, Mark (1972), "Aspects of Sectarianism in New South Wales circa 1865 to 1880", PhD Thesis, Australian National University, Canberra.

Lyons, Mark (1978), Legacy. The First Fifty Years, Lothian, Melbourne. 
Lyons, Mark (1985), "The Politics of Community Programmes". Paper presented to Australasian Social Policy and Administration Conference, Melbourne.

Lyons, Mark (1988), "Tod Tytherleigh", R.T. Appleyard and Boris Schedvin (eds), Australian Financiers. Biographical Essays, Macmillan Australia, South Melbourne.

Lyons, Mark (1989a) "Funding Options for Childcare and their Relation to Social Justice and Quality Issues. A Background paper prepared for a Research Conference", Child Accident Prevention Foundation of Australia and Australian Early Childhood Association, Melbourne.

Lyons, Mark (1989b), "Funding Option for Childcare. A Supplement to the Backgroup Paper". Child Accident Prevention Foundation of Australia and Australian Early Childhood Association, Melbourne.

Molony, John N (1969), The Roman Mould of the Australian Catholic Church, Melbourne U.P., Melbourne.

O'Brien, Anne (1988), Poverty's Prison. The Poor in New South Wales 18801918, Melbourne University Press, Melbourne.

Strahan, Ronald (ed), 1979, Rare and Curious Specimens. An Illustrated History of the Australian Museum 1827-1979. The Australian Museum, Sydney.

Ware, Alan (1989), Between Profit and State. Intermediate Organisations in Britain and the United States, Polity Press, Cambridge.

Weisbrod, Burton A (1986) "Toward a Theory of the Voluntary Nonprofit Sector in a Three-Sector Economy", Susan Rose-Ackerman (ed), The Economics of Nonprofit Institutions. Studies in Structure and Policy, Oxford University Press, New York. 